\title{
Variability in aerobic methane oxidation over the past 1.2 Myrs recorded in microbial biomarker signatures from Congo fan sediments
}

\author{
Helen M. Talbot ${ }^{\mathrm{a}, *}$, Luke Handley ${ }^{\mathrm{a}}$, Charlotte L. Spencer-Jones ${ }^{\mathrm{a}}$, \\ Dinga Jean Bienvenu ${ }^{b}$, Enno Schefuß ${ }^{c}$, Paul J. Mann ${ }^{d}$, John R. Poulsen ${ }^{\mathrm{e}}$, \\ Robert G.M. Spencer ${ }^{\mathrm{f}}$, Jose N. Wabakanghanzi ${ }^{\mathrm{g}}$, Thomas Wagner ${ }^{\mathrm{a}}$ \\ ${ }^{a}$ School of Civil Engineering and Geosciences, Drummond Building, Newcastle University, Newcastle upon Tyne, NE1 7RU, UK \\ ${ }^{\mathrm{b}}$ Groupe de Recherche en Sciences Exactes et Naturelles (GRSEN/DGRST), Ministere de la Recherche Scientifique, Brazzaville, Congo \\ ${ }^{\mathrm{c}}$ MARUM - Center for Marine Environmental Sciences, University of Bremen, D-28359 Bremen, Germany \\ ${ }^{\mathrm{d}}$ Northumbria University, Department of Geography, Newcastle Upon Tyne, UK \\ ${ }^{\mathrm{e}}$ Nicholas School of the Environment, Duke University, P.O. Box 90328, Durham, NC 27708, USA \\ ${ }^{\mathrm{f}}$ Woods Hole Research Center, 149 Woods Hole Road, Falmouth, MA 02540, USA \\ ${ }^{g}$ Department of Soil Physics and Hydrology, Congo Atomic Energy Commission, P.O. Box 868, Kinshasa XI, Democratic Republic of the Congo
}

Received 7 October 2013; accepted in revised form 24 February 2014; Available online 11 March 2014

\begin{abstract}
Methane $\left(\mathrm{CH}_{4}\right)$ is a strong greenhouse gas known to have perturbed global climate in the past, especially when released in large quantities over short time periods from continental or marine sources. It is therefore crucial to understand and, if possible, quantify the individual and combined response of these variable methane sources to natural climate variability. However, past changes in the stability of greenhouse gas reservoirs remain uncertain and poorly constrained by geological evidence. Here, we present a record from the Congo fan of a highly specific bacteriohopanepolyol (BHP) biomarker for aerobic methane oxidation (AMO), 35-aminobacteriohopane-30,31,32,33,34-pentol (aminopentol), that identifies discrete periods of increased AMO as far back as 1.2 Ma. Fluctuations in the concentration of aminopentol, and other 35-aminoBHPs, follow a pattern that correlates with late Quaternary glacial-interglacial climate cycles, with highest concentrations during warm periods. We discuss possible sources of aminopentol, and the methane consumed by the precursor methanotrophs, within the context of the Congo River setting, including supply of methane oxidation markers from terrestrial watersheds and/or marine sources (gas hydrate and/or deep subsurface gas reservoir). Compound-specific carbon isotope values of $-30 \%$ to $-40 \%$ for BHPs in ODP 1075 and strong similarities between the BHP signature of the core and surface sediments from the Congo estuary and floodplain wetlands from the interior of the Congo River Basin, support a methanotrophic and likely terrigenous origin of the 35-aminoBHPs found in the fan sediments. This new evidence supports a causal connection between marine sediment BHP records of tropical deep sea fans and wetland settings in the feeding river catchments, and thus tropical continental hydrology. Further research is needed to better constrain the different sources and pathways of methane emission. However, this study identifies the large potential of aminoBHPs, in particular aminopentol, to trace and, once better calibrated and understood, quantify past methane sources and fluxes from terrestrial and potentially also marine sources.
\end{abstract}

(c) 2014 The Authors. This is an open access article under the CC BY license (http://creativecommons.org/licenses/by/3.0/).

\footnotetext{
* Corresponding author. Tel.: +44 0191208 6426; fax: +44 01912085431.

E-mail address: helen.talbot@ncl.ac.uk (H.M. Talbot).
} 


\section{INTRODUCTION}

Methane $\left(\mathrm{CH}_{4}\right)$ is a potent greenhouse gas (GHG) estimated to currently contribute about $20 \%$ to total global atmospheric radiative forcing (IPCC, 2007). However, the different pathways of biochemical cycling of methane, which exert a primary control on atmospheric and marine $\mathrm{CH}_{4}$ concentrations through its production and microbiological consumption, remain poorly constrained. Methane emissions from natural sources are significant, although there are also large uncertainties (28-43\%; Kroeger et al., 2011 and references therein). For example, in the terrestrial realm wetlands are the largest natural source of methane, estimated to account for about $70 \%$ of natural emissions and $40 \%$ of total emissions, with other main natural sources being termites $(13 \%)$, oceans $(6 \%)$ and a range of others (9\%; Wuebbles and Hayhoe, 2002).

Furthermore, changes in the strength of tropical methane sources and sinks (i.e. wetlands, atmospheric oxidation), have been shown to exert a significant control on the atmospheric methane budget over the last 800,000 years (e.g. Blunier et al., 1995; Loulergue et al., 2008; Singarayer et al., 2011). Such changes were modulated by fluctuations in the hydrological cycle and the extent of periglacial wetlands (Loulergue et al., 2008).

Methane production is also substantial in the marine realm (Reeburgh, 2007), although under modern climate conditions up to $90 \%$ of methane produced in aquatic environments is believed to be oxidised before it reaches the atmosphere, resulting in a significantly reduced contribution to total global GHG emissions. However, the efficiency of this marine filter may not have been constant over time: proportionally more marine-derived methane may have escaped from marine sediments and reached the atmosphere, thus contributing to global greenhouse forcing, at least transiently during periods of rapid climate change. The wide range of relationships and feedbacks between marine microbially-mediated turnover of methane, the OceanClimate System and biogeochemical cycles are poorly constrained and further elucidation of the underlying drivers of such processes is critical to improve reconstructions of past climate drivers.

To date, research into the marine microbial oxidation of $\mathrm{CH}_{4}$ has largely focussed on the anaerobic oxidation of methane (AOM), as this process may remove as much methane in shallow sediments as is oxidised aerobically in terrestrial environments and the atmosphere (Boetius and Suess, 2004 and references therein). However, aerobic methane oxidation (AMO) has been proposed as playing another key role by acting to remove methane from the water column and in turn limiting emissions to the atmosphere (Valentine et al., 2001; Abril et al., 2007). Despite its potential importance in regulating marine methane fluxes, the role of marine AMO in global methane and carbon cycling, as well as the occurrence and importance of this process in the past, has received far less attention and remains poorly constrained (e.g. Valentine, 2011).

The biochemical cycling of methane, both on land and in the ocean, is believed to have been an important component of the global carbon cycle since the Archaean (e.g.
Kasting, 2005; Eigenbrode et al., 2008) and is assumed to have perturbed global climate in the past, especially when released in large quantities over short time periods (Dickens et al., 1995; Norris and Roehl, 1999; Dickens, 2003; Kennett et al., 2003; Kemp et al., 2005; Wagner et al., 2007, 2008; Etiope et al., 2008; Zeebe et al., 2009; De Conto et al., 2012). In addition to these punctuated perturbations in the past, ice-core records spanning the last 800,000 years reveal direct and periodic fluctuations in atmospheric methane concentrations, with higher values during interglacials (e.g. Loulergue et al., 2008). As such, understanding methane cycling and how microbial methane cycling and metastable $\mathrm{CH}_{4}$ reservoirs drive or respond to changes in climate is crucial, as is the fate of methane once released from such reservoirs. To that end it is necessary to identify and develop diagnostic markers (proxies), which can be applied to the sedimentary archive.

The main scope of this study is to present a novel biomarker concept to investigate microbial AMO in marine sediments and its links with tropical continental hydrology and climate. For this purpose we use the sediment section covering the past 1.2 Ma from Ocean Drilling Program (ODP) Site 1075, located on the lower Congo fan. This setting is well-documented for methane seepage (Gay et al., 2007) as well as for having a significant but variable terrigenous contribution that has been closely linked to orbitallydriven variations in monsoonal forcing and tropical African climate (Schneider et al., 1997), modulated by sea surface temperature variations (Schefuß et al., 2003, 2005). These features make the Congo Fan well suited to test a novel biomarker proxy for AMO in the sedimentary record, and discuss how possible variations in such biomarker concentrations are linked with Quaternary climate cycles and possible marine and terrestrial sources.

\section{BIOHOPANOID BIOMARKERS FOR RECONSTRUCTING METHANE CYCLING IN THE PAST}

\subsection{Biological sources and lipid composition}

Aerobic methane oxidising bacteria of the Phylum proteobacteria are divided into two groups with members of the gammaproteobacteria collectively known as Type I and the alphaproteobacteria, Type II (e.g. Hanson and Hanson, 1996). These organisms produce a range of biomarkers including common $\mathrm{C}_{30}$ hopanoids diploptene ( $\mathbf{I}$; see appendix) and diplopterol (II) which are biosynthesised by all hopanoid producers, not just methanotrophs (e.g. Rohmer et al., 1984). Methanotrophs also produce a group of distinctive extended hopanoids called bacteriohopanpolyols (BHPs) with an amine functionality at the terminal C-35 positions and 3, 4 or 5 additional hydroxyls (e.g. Cvejic et al., 2000; van Winden et al., 2012a).

The hexafunctionalised BHP 35-aminobacteriohopane30,31,32,33,34-pentol (III, aminopentol) is considered specific to Type I aerobic methane oxidising bacteria based on culture studies (e.g. Neunlist and Rohmer, 1985a; Zhou et al., 1991; Cvejic et al., 2000; Talbot et al., 2001; van Winden et al., 2012a). Two other aminoBHPs are 
commonly reported including the pentafunctionalised 35aminobacteriohopane-31,32,33,34-tetrol ( $\mathbf{V}$; aminotetrol), produced by most Type I and II methanotrophs (Neunlist and Rohmer, 1985a,b; Cvejic et al., 2000; Talbot et al., 2001) with the exception of the Type II genera Methylocella (van Winden et al., 2012a,b). Finally the tetrafunctionalised 35-aminobacteriohopane-32,33,34-triol (IV; aminotriol) is synthesised by all Type II and some Type I methanotrophs (e.g. Neunlist and Rohmer, 1985b; Cvejic et al., 2000; Talbot et al., 2001; van Winden et al., 2012a); however, it is also produced by a wide variety of other organisms (e.g. Talbot and Farrimond, 2007 and references therein).

Some Type I methanotrophs also produce a group of 35-amino-BHPs methylated at the C-3 position (see appendix) including 3 $\beta$-methyl-35-aminobacteriohopane30,31,32,33,34-pentol (3-methylaminopentol; IIIc) and the pentafunctionalised homologue 3-methylaminotetrol (Va). Production of any C-3 methylated BHP appears to be limited to those organisms which contain the recently identified $h p n R$ gene (Welander and Summons, 2012). The hpnR gene was identified in only 3 of 9 methanotroph genomes including the Type I Methylococcus capsulatus, as expected based on prior culture studies (e.g. Neunlist and Rohmer, 1985a; Summons et al., 1994; Jahnke et al., 1999). Although not currently present in the genomic database, the presence of $h p n R$ must also be inferred for the related Type I genera Methylocaldum, for which there is supporting data from culture studies demonstrating production of C-3 methylated aminotetrol and aminopentol (Cvejic et al., 2000). The $h p n R$ gene was also identified in two species of another Type I genera Methylomicrobium (Welander and Summons, 2012); however, to the best of our knowledge, actual synthesis of methylated BHPs has not been demonstrated for this genera and the one literature report we know of identified production of aminotriol and aminotetrol but not aminopentol (Talbot et al., 2001), so it may produce C-3 methylated homologues but possibly only of the tetraand pentafunctionalised aminoBHPs.

Although the identity of the other methanotroph genomes interrogated in the Welander and Summons (2012) study are not indicated, culture based investigations of the BHP composition of other Type I species have revealed that production of aminopentol without the co-occurrence of the methylated homologue is a common feature, particularly in members of the Type I genera Methylomonas (e.g. Neunlist and Rohmer, 1985a; Summons et al., 1994; Jahnke et al., 1999; Talbot et al., 2001; van Winden et al., 2012a) and more recently in Methylovulum sp. (van Winden et al., 2012a). Furthermore, no Type II methanotrophs have ever been found to make methylated BHPs (e.g. Neunlist and Rohmer, 1985b; Cvejic et al., 2000; Talbot et al., 2001; Van Winden et al., 2012a) and were not reported as containing the hpnR gene (Welander and Summons, 2012).

Whilst a range of non-methanotroph sources are known for aminotriol (e.g. Talbot and Farrimond, 2007 and references therein), reports of additional sources of aminotetrol (IV) are limited to low levels (aminotriol: aminotetrol in the range 20-100:1) in a few members of the genus Desulfovibrio (deltaproteobacteria, sulphate reducing bacteria [SRB]; Blumenberg et al., 2006, 2009a, 2012). Trace levels of aminopentol were also reported in one of these organisms (D. salexigens, ratio aminotriol: aminopentol of 1352:1; Blumenberg et al., 2012). Given the extremely low level of aminopentol in D. salexigens the same authors stated in a subsequent paper that aminopentol "remains an excellent biomarker for Type I aerobic methanotrophs" (Berndmeyer et al., 2013).

\subsection{Aminopentol - a diagnostic marker for AMO in the sedimentary record}

The development of liquid chromatography-mass spectrometry techniques has allowed the direct identification of intact biohopanoid structures including aminopentol in bacterial cultures and various environmental matrices (soils, peat, sediments, water column particulates (e.g. Talbot et al., 2001; Talbot and Farrimond, 2007; Talbot et al., 2008; Sáenz et al., 2011a; van Winden et al., 2012a). Subsequently, the observation of aminopentol (III) has been proposed as a diagnostic marker for Type I methanotrophs and its occurrence in a range of settings was used to infer AMO activity of Type I methanotrophs. For example, it has been identified (without the co-occurrence of the C-3 methylated homologue) in a wide range of environmental samples including Antarctic lake sediment where Methylomonas sp. DNA was also recovered (Ace Lake; Coolen et al., 2008). Other examples include Yangtze River Estuary sediments where peak aminopentol concentrations were found precisely at the point in the river where water column methane concentrations showed a rapid decline (Zhu et al., 2010). Non-methylated aminopentol was also reported in a range of other locations including: a range of lake sediments but excluding sites with high sulfate levels (Talbot et al., 2003; Talbot and Farrimond, 2007; Coolen et al., 2008), Amazonian wetland, shelf and deep sea fan sediments (Wagner et al., 2014), soils (e.g. Cooke, 2010), peat (Kim et al., 2011; van Winden et al., 2012a,b), a hot spring microbial mat (Zhang et al., 2007), one sample of River water from the Pacific coast of Panama (Sáenz et al., 2011a) and the water column of the Baltic Sea (Berndmeyer et al., 2013).

In combination with earlier work using less specific gas chromatography techniques which allowed the BHPs to be identified only at the level of degree of functionalisation (tetra-, penta- or hexafunctionalised [e.g. IV, V, III respectively]; e.g. Innes et al., 1997; Farrimond et al., 2000; Talbot et al., 2003), it has repeatedly been demonstrated that hexafunctionalised BHPs are only common and abundant in terrestrial systems. Conversely, tetrafunctionalised BHPs always dominate in marine settings (e.g. Farrimond et al., 2000; Watson, 2002; Blumenberg et al., 2009b, 2010; Sáenz et al., 2011a,b).

In comparison to observations of aminopentol, reports of 3-methylaminopentol (IIIc) (with or without 3-methylaminotetrol, Va) in modern samples are extremely limited, including one lake sediment (Talbot and Farrimond, 2007), a geothermal silica sinter deposit (Gibson et al., 2008) and the water column of the Black Sea (Blumenberg et al., 2007); although another study of Black Sea water column samples found only the non-methylated aminopentol 
homologue (Wakeham et al., 2007) and aminopentol has not been reported from Black Sea sediments (Blumenberg et al., 2009b). This as yet unexplained miss-match between observations of the C-3 methylated biohopanoids in modern studies and the more widespread reports of 3-methyl degradation products (see Section 2.3) was first noted by Farrimond et al. (2004).

\section{3. $\mathrm{C}_{30}$ hopanoids and geohopanoid markers of $\mathrm{AMO}$}

The hopanoid biomarkers diploptene and diplopterol (I and II respectively; see Appendix for structures) reported from recent sediments, such as the Santa Barbara Basin (northwestern Pacific; 44 ka; Hinrichs, 2001; Hinrichs et al., 2003), the western North Pacific (Uchida et al., 2004) and the Sea of Marmara (northeastern Mediterranean; during the last deglaciation; Menot and Bard, 2010), have been used to infer methane cycling. However, these biomarkers are not specific to aerobic methane oxidisers as they are also produced by a variety of other organisms (e.g. cyanobacteria, nitrogen-fixing bacteria; e.g. Rohmer et al., 1984), and therefore complimentary, more diagnostic evidence is required to confirm such a source, such as a highly depleted carbon isotope composition of the biomarkers.

Methanotrophs use different carbon assimilation pathways for methane with Type I methanotrophs using the ribulose monophosphate (RuMP) pathway and Type II methanotrophs using the serine pathway (e.g. Hanson and Hanson, 1996). An additional group of Type I organisms (formerly known as Type X), including Methylococcus sp., use the RuMP pathway as well as the reductive pentose phosphate and serine pathways (Jahnke et al., 1999). Differences in these assimilation pathways result in significant variation in carbon isotope fractionation between the carbon source, which are also linked to the particular type of methane monooxygenase enzyme (MMO) which is expressed by the organism. The membrane bound particulate methane monooxygenase (pMMO) enzyme typically results in greater fractionation leading to more depleted $\delta^{13} \mathrm{C}$ lipid values in Type I and X methanotrophs. Conversely, studies have shown that lipids produced by Type II methanotrophs, capable of expressing both pMMO and a soluble form of the enzyme sMMO, can range from $10 \%$ enriched to $12 \%$ depleted (Summons et al., 1994; Jahnke et al., 1999). However, this differentiation between Type I and Type II organisms can be further complicated by the fact that some Type I Methylomonas-like species isolated from a freshwater environment contained both pMMO and sMMO (Auman et al., 2000; Auman and Lidstrom, 2002).

Hopanes, including C-3 methylated hopanes are the defunctionalised diagenetic products of the BHPs (e.g. Farrimond et al., 2004). They have been reported from rocks dating back to the late Archean (e.g. Eigenbrode et al., 2008) and, as for the $\mathrm{C}_{30}$ biohopanoids, in combination with ${ }^{13} \mathrm{C}$ depleted carbon isotope values, have been used as molecular evidence for AMO (e.g. Collister et al., 1992). A particular focus has been marine cold seeps where geohopanoids (hopanoic acid and hopanes) with a wide range of depleted $\mathrm{C}$ isotope compositions have been reported ( -60 to $<-110 \%$; e.g. Burhan et al., 2002; Thiel et al., 2003; Peckmann and Thiel, 2004; Birgel et al., 2006a,b).

\subsection{Summary for this study}

Biological sources of the 3-methylhopanoids appear relatively restricted (Welander and Summons, 2012) and when supported by significantly depleted $\mathrm{C}$ isotope compositions have been demonstrated to be useful indicators of AMO (e.g. Collister et al., 1992; Burhan et al., 2002; Peckmann and Thiel, 2004; Birgel et al., 2006a,b). However, these compounds are in fact only produced by a small subset of methanotrophs (Neunlist and Rohmer, 1985a; Cvejic et al., 2000) and their precursor BHPs in modern systems are proving to be highly elusive. Therefore in this study we take the relatively novel approach of using aminopentol (III) as a biomarker for Type I methanotrophs and AMO.

\section{MATERIALS AND METHODS}

\subsection{Site location and sample description}

ODP Site 1075 was drilled as part of Ocean Drilling Program (ODP) Leg 175 and is situated on the Northern part of the Congo deep-sea fan $\left(4^{\circ} 47.1198^{\prime} \mathrm{S}, 10^{\circ} 4.4989^{\prime} \mathrm{E}\right.$; Fig. 1) at $2996 \mathrm{~m}$ water depth (e.g. Wefer et al., 1998). The collected sediments are bioturbated monotonous greenish-grey clays. The age model for ODP 1075 was adopted from Jahn et al. (2005) with the age assignment of marine isotope stages and sub-stages according to Lisiecki and Raymo (2005).

The sediment sample from the estuary of the Congo River ('Anker 24') was taken as grab sample (Eisma et al., 1978) and stored as dried sediment before analyses. Additional lipid data were published earlier (Schefuß et al., 2004).

Soil samples were collected from 22 sites spanning a wide range of land cover types, ranging from scrub savannah and grasslands, secondary forest and pristine tropical mixed forest, to tropically seasonally flooded and swamp forest environments within the Congo Basin (Fig 1; Table S2). Surface soils $(0-5 \mathrm{~cm})$ were collected during the months of November 2010 and August 2011. Sites were located approximately 5-30 m from nearby streams and rivers. Samples were wrapped in clean foil and shipped to Newcastle University (UK) within three weeks of collection. Samples were stored frozen on arrival and were freeze-dried and ground prior to lipid extraction.

Malebo Pool floodplain wetland sediments were collected along a transect at three sites encompassing sediment that is permanently flooded, sediment inundated during high discharge months only and sediment from above the seasonal high water point (Fig. 1). At each of the three sites sediment was collected at two distinct depths $(0-5 \mathrm{~cm}$ and $5-15 \mathrm{~cm})$, i.e. a surface and sub-surface sample. Samples were immediately frozen and shipped to the University of Newcastle-upon-Tyne (UK). Previous work has shown that OM exported from this site at the Malebo Pool is geochemically similar to $\mathrm{OM}$ at the head of the estuary $(\sim 350 \mathrm{~km}$ 


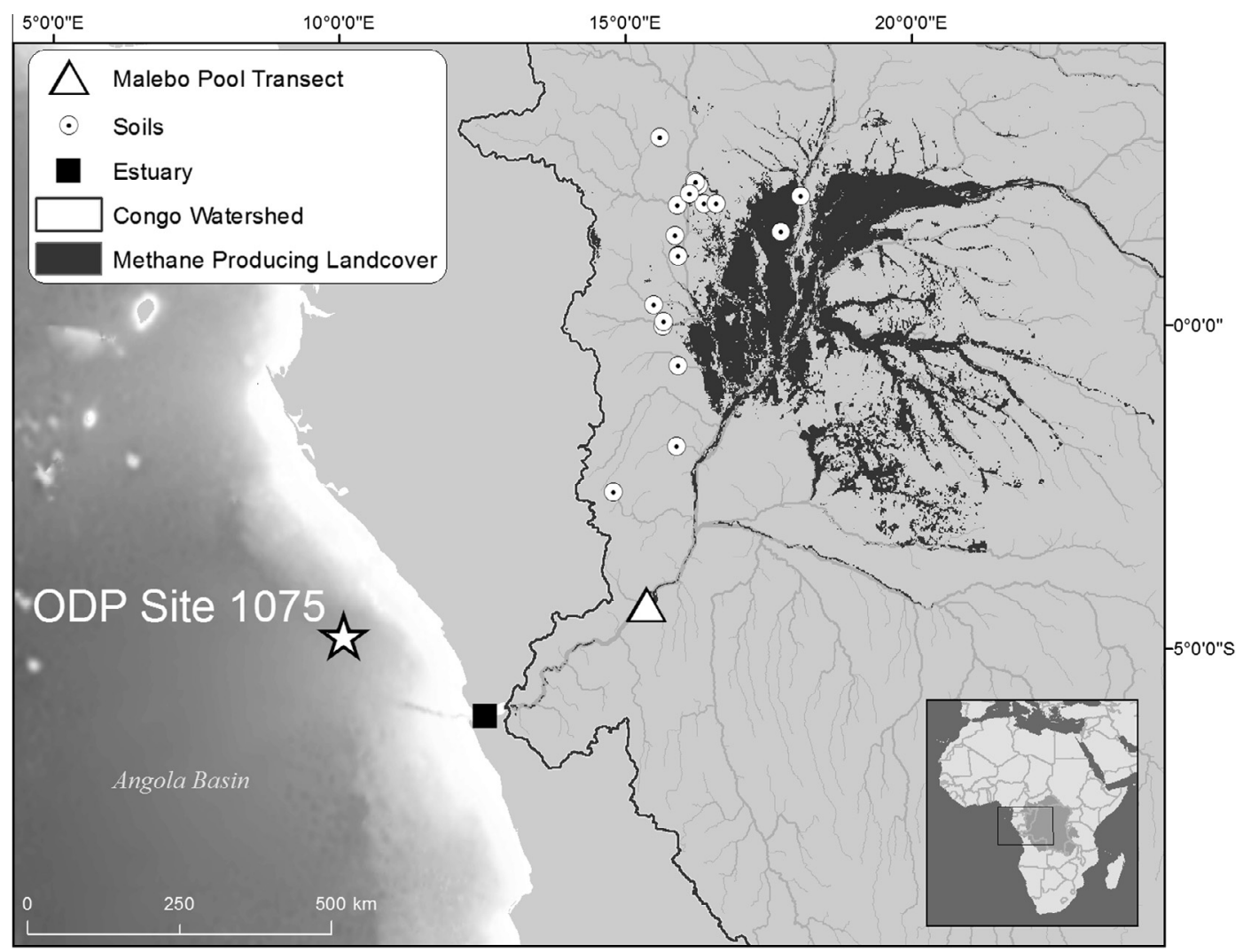

Fig. 1. Geographical location of the study site on the Congo deep sea fan. The map shows the location of Ocean Drilling Program (ODP) Site 1075 on the northern part of the Congo fan at $2995 \mathrm{~m}$ water depth as well as the locations of the estuarine and floodplain wetland sediment and soil samples. The map was plotted using the planiglobe beta online plotting service (http://www.planiglobe.com/omc_set.html).

downstream) and no major tributaries join the Congo River between this site and the Atlantic Ocean (Spencer et al., 2012).

\subsection{Total organic carbon analysis}

TOC of the ODP 1075 samples was measured as detailed in Holtvoeth et al. (2001). TOC of the soils and Malebo pool samples was measured at Newcastle University using a LECO CS244 Carbon/Sulfur Analyser after removal of inorganic carbon by treatment with hydrochloric acid.

\subsection{Lipid extraction}

Freeze-dried sediments and soils (ca. 3 g) were extracted using a modified Bligh and Dyer extraction method as described by Cooke et al. (2008). Material was extracted in a Teflon centrifuge tube by adding a monophasic solution of water/methanol $(\mathrm{MeOH}) /$ chloroform $(4 \mathrm{ml}: 10 \mathrm{ml}: 5 \mathrm{ml})$. The mixture was sonicated at $40^{\circ} \mathrm{C}$ for $1 \mathrm{~h}$ followed by shaking at room temperature for a further $2-4 \mathrm{~h}$. The mixture was then centrifuged at $12,000 \mathrm{rpm}$ for $15 \mathrm{~min}$ and the supernatant transferred to a second centrifuge tube. The same monophasic solution was again added to the initial tube and the extraction procedure repeated twice with the supernatant decanted each time. Chloroform and water ( $5 \mathrm{ml}$ each) were added to the tubes containing the supernatants and these were centrifuged for 5 min to complete the separation of the organic (chloroform) and $\mathrm{MeOH} /$ water phases. The organic fractions were then transferred to a round-bottomed flask and rotary evaporated to near dryness, transferred to a glass vial using a solution of warm (ca. $50^{\circ} \mathrm{C}$ ) chloroform/MeOH $(2: 1, \mathrm{v} / \mathrm{v})$ and then evaporated to dryness under a stream of $\mathrm{N}_{2}$ to yield the total lipid extract (TLE). A $5 \alpha$-pregnane-3 $\beta, 20 \beta$-diol internal standard was added to the TLE, which was then split into three equal aliquots following dilution with $5 \mathrm{ml}$ chloroform/ $\mathrm{MeOH}\left(2: 1, \mathrm{v} / \mathrm{v}\right.$; heated at $50^{\circ} \mathrm{C}$ for $\left.10 \mathrm{~min}\right)$.

\subsection{Bacteriohopanepolyol analysis}

An aliquot (one third) of the TLE was used for bacteriohopanepolyol (BHP) analysis: the aliquot was evaporated to dryness under $\mathrm{N}_{2}$ and acetylated by adding acetic anhydride and pyridine $\left(1 \mathrm{ml}\right.$ each) and heating at $50{ }^{\circ} \mathrm{C}$ for $1 \mathrm{~h}$ then left at room temperature overnight to yield acetylated BHPs. The acetic anhydride and pyridine were removed under a stream of $\mathrm{N}_{2}$ and the resulting acetylated extract was dissolved in $1 \mathrm{ml} \mathrm{MeOH} /$ propan-2-ol (3:2, v/v).

BHP analysis was performed by reversed-phase high performance liquid chromatography-atmospheric pressure chemical ionisation-mass spectrometry (HPLC-APCI-MS ${ }^{\mathrm{n}}$ ) using a ThermoFinnigan surveyor HPLC system fitted with a Phenomenex Gemini $\mathrm{C}_{18}$ column $(150 \mathrm{~mm}$; $3.0 \mathrm{~mm}$ i.d.; $5 \mu \mathrm{m}$ particle size) and a security guard column cartridge of the same material coupled to a Finnigan LCQ ion-trap 
mass spectrometer equipped with an APCI source operated in positive ion mode. Chromatographic separation was accomplished at $30{ }^{\circ} \mathrm{C}$ with a flow rate of $0.5 \mathrm{ml} . \mathrm{min}^{-1}$ and the following mobile phase solvent gradient: $90 \% \mathrm{~A}$, $10 \% \mathrm{~B}(0 \mathrm{~min}) ; 59 \% \mathrm{~A}, 1 \% \mathrm{~B}, 40 \% \mathrm{C}$ (at $25 \mathrm{~min}$ ); isocratic to $45 \mathrm{~min}$ returning to the starting conditions in $5 \mathrm{~min}$ and stabilising for $10 \mathrm{~min}$ (where $\mathrm{A}=\mathrm{MeOH}, \mathrm{B}=$ water and $\mathrm{C}=$ propan-2-ol). APCI was achieved at $155^{\circ} \mathrm{C}$ capillary temperature and $490{ }^{\circ} \mathrm{C}$ APCI vaporiser temperature with a corona discharge current of $8 \mu \mathrm{A}$, sheath and auxiliary gas flow of 40 and 10 , respectively (arbitrary units). $\mathrm{MS}^{\mathrm{n}}$ analysis was carried out in data-dependent mode with three scan events: SCAN 1: full mass spectrum, $m / z$ 300-1300; SCAN 2: data-dependent $\mathrm{MS}^{2}$ spectrum of most intense ion from SCAN 1; SCAN 3: data-dependent $\mathrm{MS}^{3}$ spectrum of most intense ion from SCAN 2. Detection was achieved at an isolation width of $\mathrm{m} / \mathrm{z} 5.0$ and fragmentation with normalised collisional dissociation energy of $35 \%$ and an activation $Q$ value (parameter determining the $\mathrm{m} / \mathrm{z}$ range of the observed fragment ions) of 0.15 . The semiquantitative estimate of BHP concentrations was achieved employing the characteristic base peak ion peak areas of individual BHPs in mass chromatograms (from SCAN 1) relative to the $m / z 345$ mass chromatogram base peak area of the acetylated $5 \alpha$-pregnane-3 $\beta, 20 \beta$-diol internal standard. Averaged relative response factors relative to the internal standard, determined from a suite of acetylated BHP standards, were used to adjust the BHP peak areas. Typical error in absolute quantification was $\pm 20 \%$, based on selected replicate analyses and BHP standards of known concentration (Cooke, 2010; van Winden et al., 2012a).

\subsection{Conversion of BHPs to primary hopanols}

Seven samples (Table 1) were selected for compoundspecific carbon isotope analysis. Highly functionalised BHPs cannot be analysed directly by gas chromatography-isotope ratio mass spectrometry (GC-IRMS) due to their low volatility and high polarity. However, it is possible to analyse the primary alcohols that are produced from BHP precursors via periodic acid reduction followed by sodium borohydride reduction (e.g. Crossman et al., 2001; Coolen et al., 2008) which converts hexa-/penta-/tetrafunctionalised BHPs to terminal $\mathrm{C}_{30} / \mathrm{C}_{31} / \mathrm{C}_{32}$ hopanols, respectively as described in detail below.

Periodic acid $\left(\mathrm{H}_{5} \mathrm{IO}_{6} ; 300 \mathrm{mg}\right)$ and tetrahydrofuran/ water $(8: 1, v / v ; 3 \mathrm{ml})$ were added to a TLE aliquot $(1 / 3$ of total TLE) in a conical flask equipped with a magnetic stirrer. This was then stirred for $1 \mathrm{~h}$ to oxidise polyols to yield aldehyde products. The solution was then transferred to a separating funnel. The flask was rinsed with $10 \mathrm{ml}$ distilled water followed by $15 \mathrm{ml}$ petroleum ether and these washes were added to the funnel, which was then gently shaken. The layers were allowed to separate and the upper (organic) layer transferred to a round bottomed flask. This was repeated 3 times. The combined organic layers were rotary evaporated to near dryness. Sodium borohydride $\left(\mathrm{NaBH}_{4}\right.$; $100 \mathrm{mg}$ ) was added to the round bottomed flask, followed by ethanol $(3 \mathrm{ml})$ and a magnetic stirrer. This was stirred for $1 \mathrm{~h}$ on a magnetic stirring plate to produce terminal alcohols by reduction of the aldehydes. A solution of potassium dihydrogen phosphate $\left(\mathrm{KH}_{2} \mathrm{PO}_{4} ; 15 \mathrm{ml} ; 100 \mathrm{mM}\right)$ was carefully added and the resultant solution transferred to a $100 \mathrm{ml}$ separating funnel. Petroleum ether $(15 \mathrm{ml})$ was added and the funnel gently shaken. The layers were allowed to separate and the upper (organic) layer transferred to a round bottomed flask. This was repeated 3 times in total. The combined organic layers were rotary evaporated to near dryness and transferred to a sample vial using dichloromethane. The solvent was removed under $\mathrm{N}_{2}$ and the hopanols were then acetylated using acetic anhydride and pyridine as described in Section 3.4.

\subsection{Compound-specific carbon isotope analysis}

Compound-specific stable carbon isotope ratios were determined for the acetylated terminal hopanols (produced by the reactions described in Section 3.5) by gas chromatography-combustion-isotope ratio mass spectrometry (GCC-IRMS) using a Thermo Trace Ultra GC with splitless injection $\left(280^{\circ} \mathrm{C}\right)$ via a Combustion III interface linked to a Thermo Delta V + IR-MS. Chromatographic separation was achieved on a fused silica capillary column $(30 \mathrm{~m} \times$ $0.25 \mathrm{~mm}$ i.d.) coated with a $0.25 \mu \mathrm{m}$ dimethyl polysiloxane stationary phase (HP-5) with the following temperature program: $50-200{ }^{\circ} \mathrm{C}$ at $15^{\circ} \mathrm{C} / \mathrm{min}$ (held for $1 \mathrm{~min}$ ),

Table 1

Selected samples from ODP 1075 subjected to compound specific stable carbon isotope analysis.

\begin{tabular}{|c|c|c|c|c|c|c|c|c|c|c|}
\hline \multirow[t]{3}{*}{ Sample } & \multirow[t]{3}{*}{ Age (ka) } & \multicolumn{6}{|c|}{ Carbon isotope values ( $\%$, VPBD) } & \multicolumn{3}{|c|}{$\%$ Hopanol derived from aminoBHP } \\
\hline & & \multicolumn{2}{|l|}{$\mathrm{C}_{30}$} & \multicolumn{2}{|l|}{$\mathrm{C}_{31}$} & \multicolumn{2}{|l|}{$\mathrm{C}_{32}$} & \multirow[t]{2}{*}{$\mathrm{C}_{30}$} & \multirow[t]{2}{*}{$\mathrm{C}_{31}$} & \multirow[t]{2}{*}{$\mathrm{C}_{32}$} \\
\hline & & avg. & S.D. & avg. & S.D. & avg. & S.D. & & & \\
\hline $3 \mathrm{H} 1 \mathrm{~W} 105$ & 65.88 & -38.9 & 0.6 & $\mathrm{~N} / \mathrm{A}^{\mathrm{b}}$ & $\mathrm{N} / \mathrm{A}$ & -30.3 & 0.4 & 78 & $\mathrm{~N} / \mathrm{A}$ & 17 \\
\hline $6 \mathrm{H} 3 \mathrm{~W} 105$ & 372.7 & -41.3 & 0.7 & -39.1 & 1.4 & -33.2 & 0.2 & 86 & 64 & 15 \\
\hline $6 \mathrm{H} 7 \mathrm{~W} 74$ & 425.23 & -40.3 & 0.7 & -34.0 & 0.1 & -33.2 & 0.7 & 74 & 80 & 15 \\
\hline 7H4W 5 & 481.38 & -40.7 & 0.6 & -34.3 & 0.8 & -29.6 & 0.7 & 93 & 49 & 52 \\
\hline 7H6W 15 & 521.12 & -40.2 & 0.7 & -34.6 & 1.4 & -35.0 & 1.0 & 83 & 60 & 34 \\
\hline $8 \mathrm{H} 3 \mathrm{~W} 65$ & 580.41 & -34.7 & 0.1 & -36.6 & 1.0 & -33.2 & 1.4 & 93 & 70 & 32 \\
\hline $8 \mathrm{H} 7 \mathrm{~W} 15$ & 629.87 & -37.9 & 0.2 & -34.5 & 0.03 & -31.7 & 1.2 & 78 & 55 & 21 \\
\hline
\end{tabular}

${ }^{\text {a }}$ Based on relative contribution of aminoBHP to total BHP (of each degree of functionalisation: Hexa-, penta- and tetrafunctionalised respectively) based on LCMS analysis.

b N/A not analysed (due to low intensity and/or absence of peak). 
$200-250{ }^{\circ} \mathrm{C}$ at $10^{\circ} \mathrm{C} / \mathrm{min}$ (held for $1 \mathrm{~min}$ ), $250-350{ }^{\circ} \mathrm{C}$ at $5^{\circ} \mathrm{C} / \mathrm{min}$, followed by an isothermal for $8 \mathrm{~min}$. Values, measured in duplicate, are determined from a pulsed reference gas calibrated from a reference Alkane A4 mixture with peak specific known isotopic values (Arndt Schimmelmann, Indiana University, USA) and reported in standard per mil notation $(\%)$ relative to Vienna PeeDee Belemnite (VPDB); analytical precision on the basis of replicate analysis of standards, was typically $\pm 0.3 \%$ and accuracy is represented by 1 sigma standard deviation (Table 1). Measured $\delta^{13} \mathrm{C}$ values were corrected to take into account the added acetate moiety, the $\delta^{13} \mathrm{C}$ value of which was determined from an acetylated androstanol standard of known isotopic composition. This approach assumes that the fractionation of the acetate group during acetylation is the same for the standard and the hopanols.

\section{RESULTS}

\subsection{Bacteriohopanepolyol concentrations}

A variety of fully functionalised BHPs have previously been reported from ODP Site 1075 sediments, with abundant BHPs in all samples (Cooke et al., 2008; Handley et al., 2010). Here, we confirm that aminopentol (III) is present in 120 of the 122 sediments analysed, as are the other aminoBHPs aminotriol (IV) and aminotetrol (V; Fig. 2) together with 2 other minor BHPs related to aminopentol (IIIa and IIIb; Table S1), up to 115 metres below sea floor (mbsf) and an estimated age of ca. 1.2 Ma based on the age model of Jahn et al. (2005). We did not find any C-3 methylated hopanoids in this study (see also Handley et al., 2010). No statistically relevant co-variation is observed between aminopentol concentration and TOC
$\left(R^{2}=0.006, p=0.392\right)$. Aminopentol concentrations vary widely throughout the core, reaching several maxima of ca. $170 \mu \mathrm{g} \mathrm{gC}_{\text {org }}^{-1}$ (Fig. 2). Such values are an order of magnitude greater than previously reported sedimentary aminopentol concentrations in river and estuarine sediments (Cooke et al., 2009; Zhu et al., 2010) and the highest reported to date from any marine sediment. Aminotriol concentrations are, generally, higher than aminopentol, with maximum values reaching ca. $360 \mu \mathrm{g} \mathrm{gC}_{\text {org. }}^{-1}$. Conversely, aminotetrol is present in subordinate quantities, with concentrations consistently a factor of ca. 5 lower than aminotriol. The concentrations of these two 35 -aminobacteriohopanepolyols also vary significantly over the last $1.2 \mathrm{Myr}$ and their changes generally mirror those in aminopentol concentration (Fig. 2). Linear regression of concentrations of aminopentol vs. aminotriol and aminotetrol show highly significant correlations with $R^{2}$ values of $0.69(p=<0.001)$ and $0.81(p=<0.001)$, respectively.

Within the uncertainties of accuracy of the age model (Jahn et al., 2005) there appears to be a relationship between aminopentol concentrations and marine isotope stages (MIS), which are defined by shifts in global ocean oxygen isotopic composition (Lisiecki and Raymo, 2005): concentrations are generally higher during interglacial stages (Fig. 2). Some slight mismatches in the positioning of the aminopentol maxima at the glacial/interglacial transitions (e.g. around 680 and $245 \mathrm{kyr}$ ) may arise due to the limited resolution of the aminopentol record and limitations inherent in the age model. It should also be noted that the pronounced shifts in aminoBHP concentrations observed in the Congo core are unlikely to be the result of a preservational bias as the same relationship is also observed if the aminoBHPs are plotted as a proportion of total BHPs
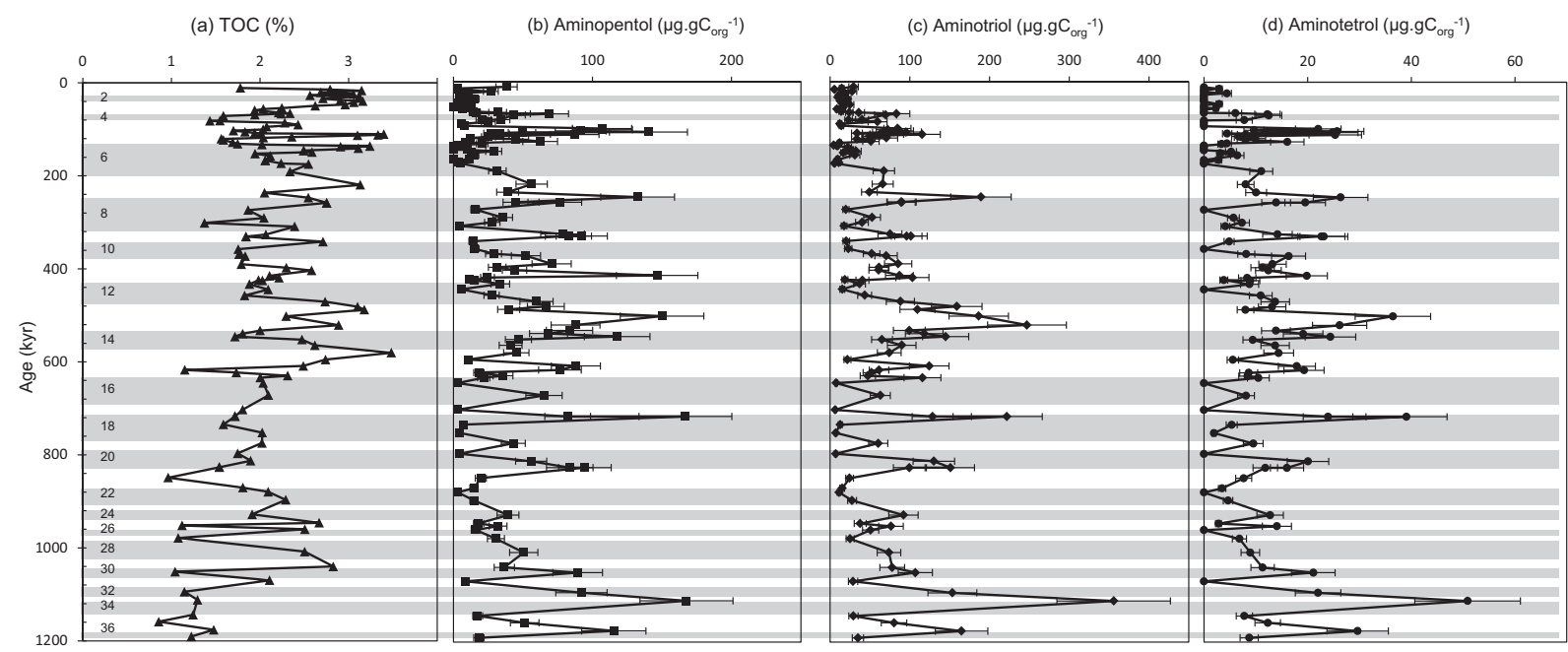

Fig. 2. TOC and 35-AminoBHP concentrations from ODP Site 1075 on the Congo deep sea fan from ca. $10 \mathrm{ka}$ to $1.2 \mathrm{Ma}$. (a) TOC (\%). (b) 35-Aminobacteriohopane-30,31,32,33,34-pentol (aminopentol). (c) 35-amino-bacteriohopane-32,33,34-triol (aminotriol). (d) 35-Aminobacteriohopane-31,32,33,34-tetrol (aminotetrol). BHP concentrations are expressed as weight per gram of sedimentary organic carbon $\left(\mu \mathrm{gC}_{\text {org }}^{-1}\right.$ ). Note that a reported concentration of $0 \mu \mathrm{g} \mathrm{gC}_{\text {org }}^{-1}$ does not necessarily represent the complete absence of aminoBHPs but indicates that concentrations were below confidence levels for integration. Error bars represent analytical error of $\pm 20 \%$ associated with the quantification of BHPs using LC-MS. The grey shaded areas highlight glacial marine oxygen isotope stages (MIS) as defined by Lisiecki and Raymo (2005). 
(not shown). We argue that if diagenetic processes exerted a significant influence on downcore changes in concentrations they would likely affect structurally related BHPs similarly. However, other BHP records (Handley et al., 2010) do not mirror the trends observed in the aminoBHP records and there is no indication of significant diagenetic overprinting of other sedimentary BHP records at depth, except for the more labile soil marker adenosylhopane as reported previously (Cooke et al., 2008; Handley et al., 2010).

\subsection{Compound-specific carbon isotope analysis}

Hexa-, penta- and tetrafunctionalised biohopanoids were converted to terminal $\mathrm{C}_{30}, \mathrm{C}_{31}$ and $\mathrm{C}_{32}$ hopanols, respectively, for compound specific isotope analysis. The measured value is therefore an integrated one for all converted biohopanoids as well as free-hopanols possessing the same degree of functionality, which were already present in the sediment. Assuming a minimum contribution from pre-existing free hopanols, the relative contribution of 35-aminobacteriohopanepolyol to the total hopanol concentration can be estimated via quantification using LCMS. The measured hopanol $\delta^{13} \mathrm{C}$ values are plotted against the $\%$ contribution of amino-BHP to total BHPs of each specific degree of functionality (Fig. 3). Hopanol $\delta^{13} \mathrm{C}$ values decrease as the \% contribution of aminoBHP to total precursor BHPs increases (Fig. 3; Table 1) e.g. for the $\mathrm{C}_{30}$ hopanol, the most depleted values of around $-41 \%$ are observed when the aminopentol precursor contributes ca. $90 \%$ of the total hexafunctionalised BHPs.

\subsection{BHP composition of Congo surface estuarine, wetland and soil samples}

The BHP composition of one surface sediment sample from the Congo River estuary, 3 surface and 3 subsurface sediments from the Malebo Pool and 22 soils from the continental hinterland (see Fig. 1 for locations) was investigated. All samples contain a wide variety of BHPs, with similar compounds to those found in the ODP 1075 sediments (Cooke et al., 2008; Handley et al., 2010). Here we focus on the aminoBHPs only, which are present in all samples (Table S2; Fig. 4). The BHP composition of the estuarine and wetland sediment samples closely resembl that of the Congo core sediments with strong contributions from aminotetrol and aminopentol relative to aminotriol, whereas that of the soils shows marked differences with aminotriol (Fig. 4) being by far the most dominant aminoBHP and with aminopentol observed in only 7 of the 22 samples. Aminopentol was a significant component $\left(>50 \mu \mathrm{g} \mathrm{CC}_{\text {org }}^{-1}\right)$ in only one soil (closed evergreen lowland forest sample $\mathrm{C} 18 \mathrm{~B}$; Table S2; Fig. 4) collected from a swampy area, approximately $2 \mathrm{~m}$ from a small $7 \mathrm{~m}$ wide river channel.

\section{DISCUSSION}

\subsection{A 1.2 Myr record of aerobic methane oxidation intensity}

As described above (Section 2.1), Type I methane oxidising bacteria are the only know significant source of

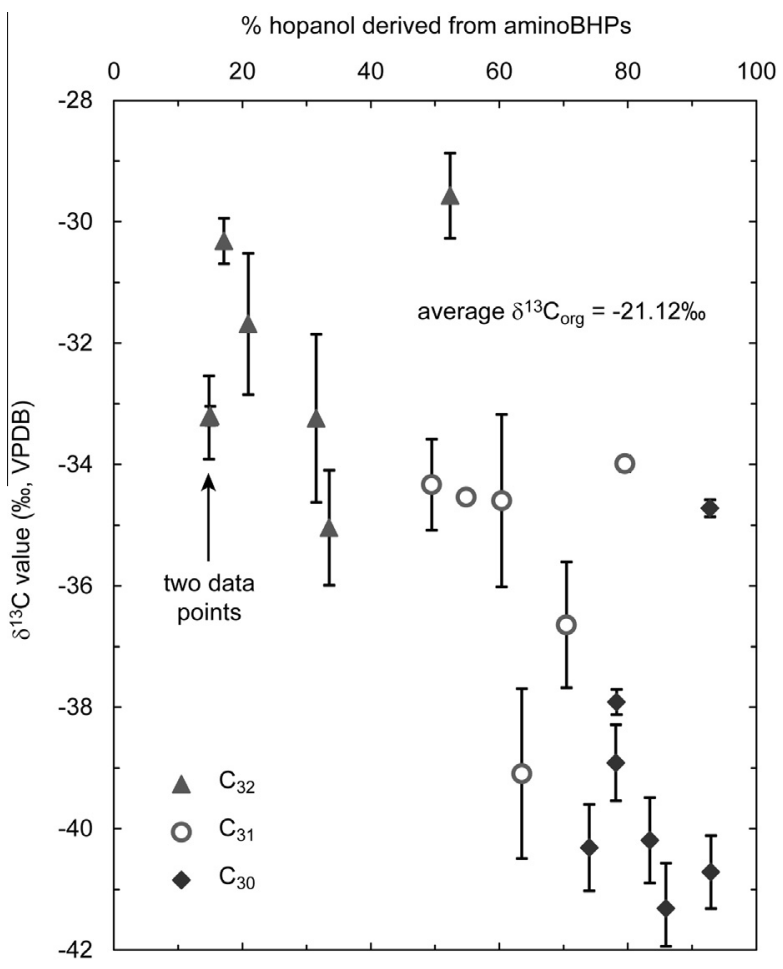

Fig. 3. Cross-plot of $\delta^{13} \mathrm{C}$ values of terminal hopanols produced by periodic acid/sodium borohydride treatment with the $\%$ hopanol derived from aminoBHPs. The $\%$ hopanol derived from an aminoBHP precursor was estimated as the $\%$ contribution of each aminoBHP to total BHPs of the same degree of functionality, based on quantification using LC-MS. Error bars represent 1 sigma standard deviation based on replicate analyses. The average $\delta^{13} \mathrm{C}_{\text {org }}$ value is the average of bulk organic carbon isotopic compositions for 303 ODP Site 1075 samples from ca. $10 \mathrm{ka}$ to $1.2 \mathrm{Ma}$ (Holtvoeth et al., 2001).

aminopentol (III). The methanotrophic origin of the 35aminoBHPs is supported, although not finally conclusive, by the compound-specific carbon isotope analyses. $\delta^{13} \mathrm{C}$ values of the hopanol derivatives with a primary hydroxyl group decrease markedly when the $\%$ derived from aminoBHP increases (Fig. 3), confirming that the aminoBHPs are substantially more ${ }^{13} \mathrm{C}$-depleted than most other BHPs and bulk organic matter (average $\delta^{13} \mathrm{C}_{\mathrm{org}}=-21 \%$; Holtvoeth et al., 2001).

The most negative carbon isotope values of ca. $-41 \%$ are not as negative as some previously reported values for biohopanoids produced by aerobic methanotrophs (e.g. Hinrichs, 2001; Coolen et al., 2008; Birgel et al., 2011), but is equivalent to the most depleted values reported for diploptene by Uchida et al. (2004) where they used variations between $-41.0 \%$ and $-27.9 \%$ to infer enhanced incorporation of ${ }^{13} \mathrm{C}$ depleted methane via methanotrophic processes. However, we also postulate that a likely source organism for the aminoBHPs in the Congo fan could be members of the Type I genera Methylomonas given the significant amount of aminopentol without the corresponding C-3 methylated homologue (see Section 2.1). Although we can only speculate, this could potentially include members of this genera which can express both pMMO and sMMO 


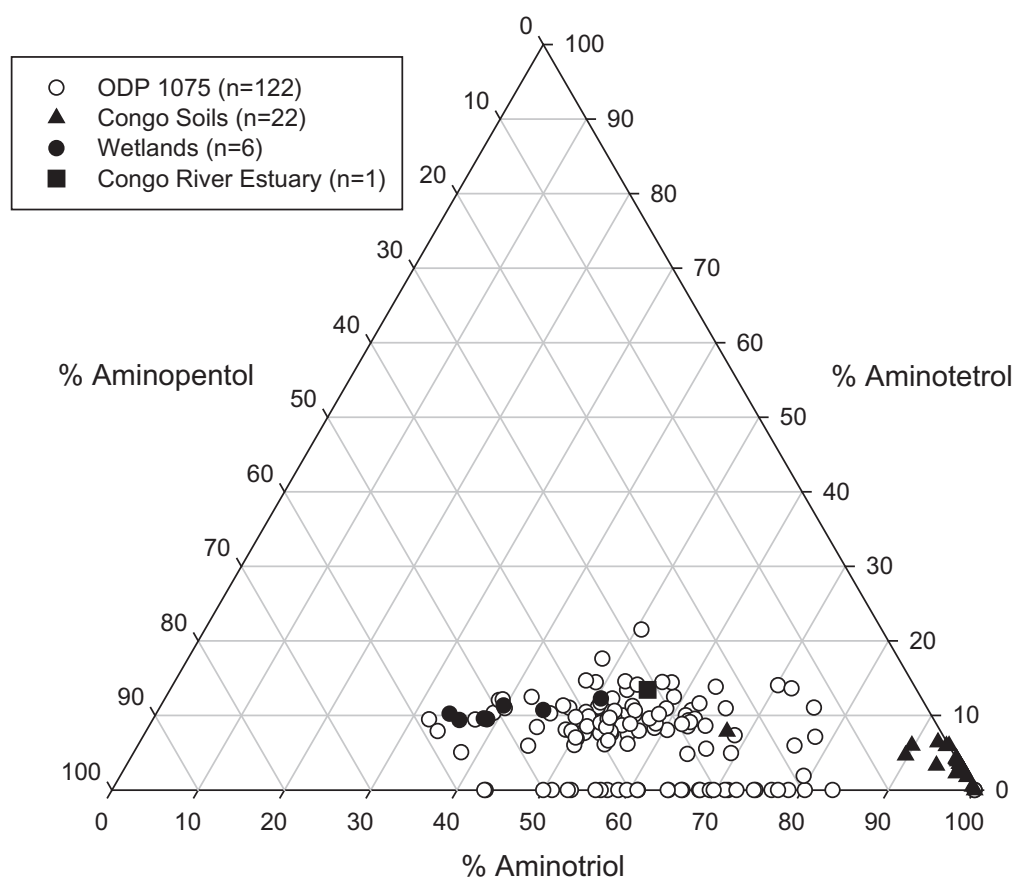

Fig. 4. Ternary plot of the relative abundance of aminoBHPs including the 3 major (aminopentol - III, aminotriol - IV and aminotetrol V) and 2 minor (IIIa and IIIb combined with aminopentol) compounds present in ODP Site 1075 sediments (122 samples), the Congo estuarine sediment, 6 wetland sediments from the vicinity of Malebo Pool and 22 soils from the Republic of Congo. See Fig. 1 for locations.

(see Section 2.3), depending on prevailing conditions as reported in freshwater isolates from Lake Washington (Auman et al., 2000; Auman and Lidstrom, 2002). Previous studies of Type II methanotrophs using sMMO have shown that their lipid carbon isotope compositions can be much more variable potentially resulting in ${ }^{13} \mathrm{C}$ enrichment as well as depletion (Jahnke et al., 1999). The studies of Type II organisms also showed that the type of MMO expressed had no effect on the BHP distribution (Jahnke et al., 1999). It may therefore be possible that the limited ${ }^{13} \mathrm{C}$ depletions observed in our study are at least partially the result of BHP production by sMMO-expressing aminopentol producers as no difference in BHP composition was observed in studies of Type II organisms when expressing sMMO vs. pMMO (Summons et al., 1994; Jahnke et al., 1999).

To the best of our knowledge there is no data on methane carbon isotope composition from the Congo system (river and/or wetlands). Tyler et al. (2007), report typical values of $-56 \%$ for swamps and marshes and $-59 \%$ for "bogs, fens and lakes" at latitudes below $60^{\circ} \mathrm{N}$, although biogenic methane produced locally under substrate limiting conditions or by methylotrophic methanogenesis may be somewhat enriched (in the region of those reported for thermogenic methane $(-50 \%$ to $-30 \%$; Jahnke et al., 1999 and references therein). At this time we can only speculate if any of these values might be representative for our source areas but if valid, then we would not expect the highly depleted values observed previously in other settings including marine cold seeps (typically in the range $-65 \%$ to $-110 \%$; e.g. Collister et al., 1992; Burhan et al., 2002; Thiel et al., 2003; Birgel et al., 2006a,b). However, less depleted $\delta^{13} \mathrm{C}$ values between $-31 \%$ and $-40 \%$, for example, have recently been reported for hopanoids with an inferred methanotrophic origin from peat bogs (van Winden et al., 2010), demonstrating the wide range of negative carbon isotope signatures derived from methanotrophs occurring in natural samples.

The strong correlation between the different aminoBHP records (Fig. 2) combined with the carbon isotopic values suggest that, although other sources cannot be discounted entirely, aminotriol and aminotetrol are likely primarily derived from the same source organism as aminopentol, or organisms that respond in similar ways to changes in environmental conditions. As aerobic methanotrophic bacteria are the only significant source of aminopentol (Cvejic et al., 2000; van Winden et al., 2012a) and, at least partially, aminotetrol and aminotriol, we conclude that changes in concentration of these biomarkers in the Congo sediments are mainly proportional to changes in methanotrophic biomass and thus the intensity of aerobic methane oxidation. Consequently, the intervals of increased sedimentary aminopentol concentration are interpreted as periods of increase in aerobic methanotroph activity, although no quantitative estimates are currently possible.

Fluctuations in the intensity of aerobic methane oxidation appear to follow the pattern of late Quaternary glacial-interglacial climate cycles and marine isotope stages (Fig. 2; based on the age model of Lisiecki and Raymo, 2005). Within the limitations of resolution of our aminopentol record, the highest activity is observed during interglacials, possibly focussed to the beginning of interglacials (near or at Terminations) when temperature and sea level rose at the highest rates. This relationship is somewhat less clear in the deeper sections of the core, which may also be due to larger uncertainties in the age model in this part of the core and/or the more sparse data coverage. 
We recognise that aminopentol concentration is not generally elevated during MIS 3, compared to other interglacial periods. It has been proposed that MIS 3 was generally less pronounced than other interglacials (e.g. Shackleton et al., 1990), suggesting that the methane cycling mechanism responsible for the aminopentol response in the sediments may also have been attenuated, in comparison to other interglacials. If correct, this suggests a causal link between shifts in Quaternary climate and aerobic methane oxidation intensity.

\subsection{Possible sources of the methane oxidation signatures on the Congo fan}

Considering the location of ODP Site 1075, aminopentol, and other BHPs, may have an allochthonous terrigenous or an autochthonous marine origin, or a combination of both. We therefore discuss possible sources of the aminopentol and, by association, the bacteria from which it was derived.

\subsubsection{Aerobic methane oxidation on land}

Aerobic methane oxidation is a widespread process in the terrestrial realm (e.g. Hanson and Hanson, 1996) and aminopentol has been reported from a range of continental environments, including soils (Cooke, 2010) peat bogs (van Winden et al., 2012a,b), river sediments (Cooke et al., 2009; Zhu et al., 2010) and lakes (Talbot and Farrimond, 2007; Coolen et al., 2008). The elevated BHP concentrations observed in the Congo core are uncommon in marine sediments and BHP concentrations are typically greater in estuarine and coastal sediments and waters than in the open ocean (Zhu et al., 2011; Sáenz et al., 2011a). In such settings, surface sediment concentrations usually decrease markedly with distance from the coast (Zhu et al., 2010, 2011; Doğrul Selver et al., 2012). A terrestrial source for aminopentol must therefore be considered very likely.

The full sedimentary aminoBHP composition provides insight into this possible terrestrial source. We compare the aminoBHP composition for all samples from the Congo core with that of the surface sediment sample from the Congo estuary, the 6 floodplain wetland sediments and 22 soil samples from throughout the Congo River Basin (Fig. 4). The BHP distribution of the soils from the hinterland is markedly different to that from the Congo fan sediments, with the exception of one soil from swampy ground (sample C18B, Table S2), implying that sedimentary BHPs in the estuary and at Site 1075 are not primarily derived from soil settings. The aminoBHP composition of the 6 floodplain wetland sediments are, however, more closely related to the composition of ODP 1075 (Fig. 4), although there are some variations, particularly in the proportion of aminotetrol (V) which is always a minor component (and frequently absent) throughout the core when compared to aminotriol and aminopentol (See Fig. 2). A terrestrial source is, however, indeed supported by compound-specific carbon isotope data as their signatures are too heavy for a purely marine microbiological source (about $-40 \%$ as opposed to $<-60 \%$; e.g. Jahnke et al., 1995; Burhan et al., 2002; Peckmann and Thiel, 2004; Birgel et al., 2006a,b).
Consequently, terrestrial BHP sources other than soils must be considered. The Congo River Basin is associated with a complex system of inland waters, seasonally inundated wetlands and includes the World's largest swamp forest found within its central depression (Cuvette Congolaise or Cuvette Centrale) and the Malebo Pool (Fig. 1), close to the outflow of the Congo River where organic matter can be produced, stored, degraded and ultimately exported to the Atlantic Ocean (Spencer et al., 2013). These processes in the Congo River Basin and their integrated export signal are poorly constrained at the moment. However, floodplain lakes and seasonally inundated wetland systems are widespread across all terrestrial ecosystems including the tropical Congo (Fig. 1; Spencer et al., 2013) and Amazon (Melack and Hess, 2010) Basins. For the latter, first BHP signatures have recently been reported and linked with marine sedimentation on the Holocene to deglacial shallow and deep Amazon fan (Wagner et al., 2014). Comparable and highly invariant BHP compositions were observed in two marine sediment records, with high relative abundance of C-35 amino-BHPs, including aminopentol, that ranged between $40 \%$ and $50 \%$ of all BHPs. The strong similarity in BHP composition in marine and floodplain sediments was used to suggest that BHPs measured in the marine sediments have initially been produced within continental wetland regions and therefore document export from terrestrial wetland regions to the marine environment, both during recent and past glacial climate conditions.

Previous studies have proposed that variations in the hydrological cycle at low latitudes are the dominant control on atmospheric methane levels due to expansion/ contraction of tropical and boreal wetlands (e.g. Blunier et al., 1995; Fischer et al., 2008; Loulergue et al., 2008). We consequently propose that wetland areas, one apparent source of the observed aminoBHP signatures, would have been expanded during more humid (interglacial) conditions concurrent with enhanced precipitation and river outflow to the shelf and deep fan. At this point it is not yet possible to deconvolute both controls, but we suggest that expansion of wetland environments during humid climate periods may have been more important than enhanced runoff, considering that large tropical rivers constantly export large volumes of freshwater and organic matter to the coastal ocean, irrespective of glacial or interglacial climate conditions.

\subsubsection{Aerobic methane oxidation from marine sources}

Alternatively, or in addition, the aminopentol record from the Congo fan may represent an autochthonous marine signal. However, to the best of our knowledge there are no reports of aminopentol from other marine sites such as cold seeps (including cold seep mussel gill symbionts) where only tetra- and pentafunctionslised biohopanoids have been reported, including but limited to aminotriol and aminotetrol (e.g. Jahnke et al., 1995; Burhan et al., 2002; Pancost et al., 2005; Birgel et al., 2011). If there is a marine source of aminopentol, it could be interpreted as an indirect record of methane emission intensity into the oxic bottom and/or pore water during or slightly after sediment deposition. The inferred increase in shallow pore water or bottom water column methane concentrations could be the result of an 
increase in sedimentary methanogenesis, linked to high surface water productivity and elevated OM flux to the sediments. The Congo records, however, do not show a clear correlation between sedimentary total organic carbon (TOC) concentration and glacial-interglacial climate cycles (Fig. 2; Holtvoeth et al., 2001), driven by fluctuations in productivity (Schneider et al., 1997) in response to variations in upwelling intensity and nutrient availability (Schneider et al., 1994; Holmes et al., 1997; West et al., 2004). We therefore conclude that changes in productivity and associated increases in organic carbon flux and shallow sedimentary methanogenesis are unlikely to be the primary cause for the observed fluctuations in methane oxidation intensity.

A second potential marine methane source is deep subsurface gas reservoirs. There is ample evidence for seafloor methane seepage in the Congo fan region based on pockmark structures (Gay et al., 2006a; Sahling et al., 2008). Giant structures of over $800 \mathrm{~m}$ in diameter have been reported that correlate with elevated methane concentrations in overlying waters (up to $20 \mu \mathrm{mol} / \mathrm{l}$; Gay et al., 2006b) and authigenic carbonate precipitates (Feng et al., 2010). Gay et al. (2007) demonstrated that most of the pockmarks on the deeper Congo Fan are currently dormant, but that they were periodically active in the past (see Noethen and Kasten, 2011 for discussion), possibly connecting to gas sources in the deep subsurface. The episodic nature of such outgassing events, however, makes a direct link to the observed glacial-interglacial climate variability unreasonable. However, there is currently no biohopanoid data from any pockmarks available to support or refute this idea.

A third and final potential marine source for methane outgassing is the presence of gas hydrates, which have been inferred on the Northern Congo fan from mud volcanoes and along the Congo continental slope near the presence of pockmark structures (Charlou et al., 2004; Sultan et al., 2004). Gas hydrates have also been recovered from the shallow subsurface at water depths of $3100 \mathrm{~m}$ in the vicinity of ODP Site 1075 (Sahling et al., 2008). Considering the observed stratigraphic relationship between aminopentol concentrations and late Quaternary climate, a shallow gas hydrate source would be consistent with enhanced methane emission into the aerobic water column especially during early interglacial periods, assuming that the AOM filter (see Jorgensen and Kasten, 2006 for further information) was not quantitative in the subsurface at temporarily very high methane fluxes from an unstable gas hydrate layer. Still, even if a gas hydrate source of the methane seems feasible within the Congo fan area, it must be considered that ODP Site 1075 is situated at $3000 \mathrm{~m}$ water depth, which under modern conditions is within the lower part of the hydrate stability zone and further discussion is beyond the scope of this study.

\section{CONCLUSIONS}

This study confirms molecular evidence for AMO, in the form of specific aminoBHPs produced by aerobic methanotrophs, in marine sediments from the Congo deep sea fan (ODP Site 1075) dating back to 1.2 Ma. Our record from the Congo fan is the first to document aerobic methane oxidation over such an extended time interval in this way and highlights natural variability in methane emission and cycling in the past. At this point we cannot categorically identify the source of the molecular signature with absolute confidence, but available data favour a continental source of the BHP signals in the Congo deep sea fan sediments. The exact origin of the BHP signature in the Congo River Basin is difficult to constrain, but close similarities between average BHP signatures in one estuarine sample from the Congo mouth and the fan sediments with those from tropical floodplain wetland sediments from the interior of the Basin strongly point towards wetland areas as the most likely source environment. At this point we cannot exclude additional in situ production of aminoBHPs in aerobic marine surface sediments and/or the overlying water column linked to short periods of enhanced destabilisation of shallow subsurface marine gas hydrates, however, there is no direct evidence to support such a source and mechanism. With the primary scope of this study being to introduce a new molecular proxy for methane cycling from the sedimentary record, more systematic studies are required to further constrain the variability of BHP composition and isotopic signatures within different source areas, both marine and terrestrial, and associated rates of methane flux.

\section{ACKNOWLEDGEMENTS}

We thank the Natural Environment Research Council (NERC) for funding (Grant number NE/E017088/1) and the Integrated Ocean Drilling Program (IODP) for supplying the sediments. We also thank the Science Research Infra-structure Fund (SRIF) from HEFCE for funding the purchase of the ThermoFinnigan LCQ ion trap mass spectrometer and Katie Anderson and Kate Osborne for technical assistance. We also thank G. J. Fiske (Woods Hole Research Centre) for assistance with preparation of Figure 1. T.W. recognizes support from the Royal Society-Wolfson Research Merit Award. This project was partially funded by a Starting Grant (No. 258734) awarded to HMT for project AMOPROX from the European Research Council to whom we are extremely grateful. R.G.M.S. acknowledges support from the NSF Emerging Topics in Biogeochemical Cycles grant number 0851101. WCS-Congo is acknowledged for essential infrastructure and accommodation during travels into the Congo River Basin.

\section{APPENDIX A.}

All BHP side structures shown (III, IV, V) have previously been unambiguously identified by NMR and side chain stereogenic centres determined by ORD measurements for all three mentioned aminopolyols (Zhou et al., 1991). When identified in this study using LC-MS only, where stereochemistry cannot be confirmed, we have assumed the structure to be the same as that previously characterised but the occurrence of additional/alternative isomers cannot be excluded. Structure IIIa includes double bond at either position C-6 or C-11 (cf. Cvejic et al., 2000). Structure, IIIb is a novel, early eluting (on reversed phased HPLC) isomer of aminopentol (III) proposed to comprise 2 hydroxyl groups located on one $\mathrm{C}$ atom which hinders full acetylation (see van Winden et al., 2012a). 


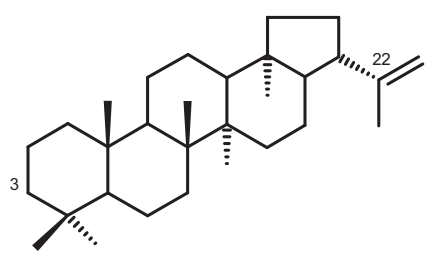

I

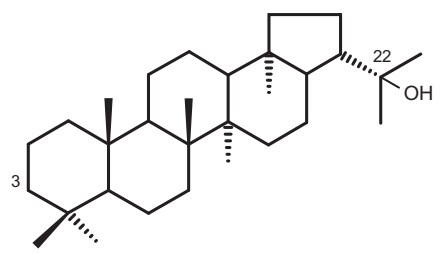

II

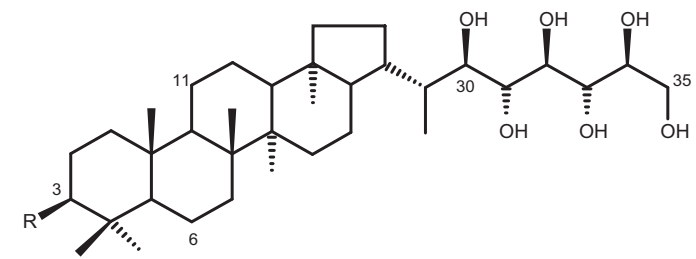

III, IIIa, IIIb $(\mathrm{R}=\mathrm{H})$, IIIc $\left(\mathrm{R}=\mathrm{CH}_{3}\right)$

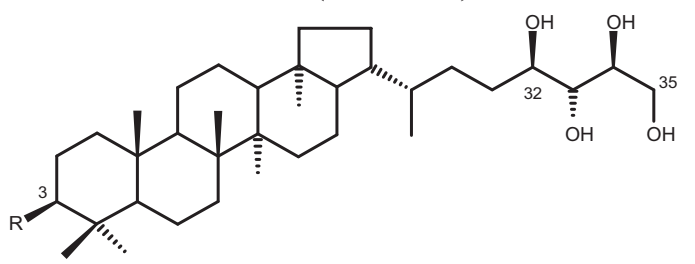

IV $(\mathrm{R}=\mathrm{H})$<smiles>[R][R]([H])=C(C)[Y10]([H])([H])C</smiles>

\section{APPENDIX B. SUPPLEMENTARY DATA}

Supplementary data associated with this article can be found, in the online version, at http://dx.doi.org/10.1016/ j.gca.2014.02.035.

\section{REFERENCES}

Abril G., Commarieu M.-V. and Guérin F. (2007) Enhanced methane oxidation in an estuarine turbidity maximum. Limnol. Oceanogr. 52, 470-475.

Auman A. J., Stolyar S., Costello A. M. and Lidstrom M. E. (2000) Molecular characterisation of methanotrophic isolates from freshwater lake sediment. Appl. Environ. Microbiol. 66, 5259-5266.

Auman A. J. and Lidstrom M. E. (2002) Analysis of sMMOcontaining Type I methanotrophs in Lake Washington sediment. Environ. Microbiol. 4, 517-524.

Berndmeyer C., Thiel V., Schmale O. and Blumenberg M. (2013) Biomarkers for aerobic methanotrophy in the water column of the stratified Gotland Deep (Baltic Sea). Org. Geochem. 55, $103-111$.

Birgel D., Thiel V., Hinrichs K.-U., Elvert M., Campbell K. A., Reitner J., Farmer J. D. and Peckmann J. (2006a) Lipid biomarker patterns of methane-seep microbialites from the Mesozoic convergent margin of California. Org. Geochem. 37, 1289-1302.

Birgel D., Peckmann J., Klautzsch S., Thiel V. and Reitner J. (2006b) Anaerobic and aerobic oxidation of methane at late cretaceous seeps in the western interior seaway, USA. Geomicrobiol J. 23, 565-577.
Birgel D., Feng D., Roberts H. H. and Peckmann J. (2011) Changing redox conditions at cold seeps as revealed by authigenic carbonates from Alaminos Canyon, northern Gulf of Mexico. Chem. Geol. 285, 82-96.

Blumenberg M., Krüger M., Nauhaus K., Talbot H. M., Oppermann B. I., Seifert R., Pape T. and Michaelis W. (2006) Biosynthesis of hopanoids by sulfate-reducing bacteria (genus Desulfovibrio). Environ. Microbiol. 8, 1220 1227.

Blumenberg M., Seifert R. and Michaelis W. (2007) Aerobic methanotrophy in the oxic-anoxic transition zone of the Black Sea water column. Org. Geochem. 38, 84-91.

Blumenberg M., Oppermann B. I., Guyoneaud R. and Michaelis W. (2009a) Hopanoid production by Desulfovibrio bastinit isolated from oilfield formation water. FEMS Microbiol. Lett. 293, 73-78.

Blumenberg M., Seifert R., Kasten S., Bahlmann E. and Michaelis W. (2009b) Euphotic zone bacterioplankton sources major sedimentary bacteriohopanepolyols in the Holocene Black Sea. Geochim. Cosmochim. Acta 73, 750-766.

Blumenberg M., Mollenhauer G., Zabel M., Reimer A. and Thiel V. (2010) Decoupling of bio- and geohopanoids in sediments of the Benguela Upwelling System (BUS). Org. Geochem. 41, $1119-1129$

Blumenberg M., Hoppert M., Krüger M., Dreier A. and Thiel V. (2012) Novel findings on hopanoid occurrences among sulfate reducing bacteria: is there a direct link to nitrogen fixation? Org. Geochem. 49, 1-5.

Blunier T., Chappellaz J., Schwander J., Stauffer B. and Raynaud D. (1995) Variations in atmospheric methane concentration during the Holocene epoch. Nature 374, 46-49. 
Boetius A. J. and Suess E. (2004) Hydrate Ridge: a natural laboratory for the study of microbial life fueled by methane from near-surface gas hydrates. Chem. Geol. 205, 291-310.

Burhan R. Y. P., Trendel J. M., Adam P., Wehrung P., Albrecht P. and Nissenbaum A. (2002) Fossil bacterial ecosystem at methane seeps: origin of organic matter from Be'eri sulphur deposit, Israel. Geochim. Cosmochim. Acta 66, 4085-4101.

Charlou J. L., Donvala J. P., Fouqueta Y., Ondreasa H., Knoerya J., Cochonata P., Levaché D., Poirierb T., Baptistec P. J., Fourré E., Chazallond B. and Zairov L. S. P. (2004) Physical and chemical characterization of gas hydrates and associated methane plumes in the Congo-Angola Basin. Elsevier Sci. Publ. Company 205, 405-425.

Collister J. W., Summons R. E., Lichtfouse E. and Hayes J. M. (1992) An isotopic biogeochemical study of the Green River oilshale. Org. Geochem. 19, 265-276.

Cooke, M. P. (2010) The role of bacteriohopanepolyols as biomarkers for soil bacterial communities and soil derived organic matter. Ph. D. thesis, Newcastle University, UK.

Cooke M. P., Talbot H. M. and Farrimond P. (2008) Bacterial populations recorded in bacteriohopanepolyol distributions in soils from Northern England. Org. Geochem. 39, 1347-1350.

Cooke M. P., van Dongen B. E., Talbot H. M., Semiletov I., Shakhova N., Guo L. and Gustafson Ö. (2009) Transport of terrestrial organic matter to the Arctic Ocean via the great Arctic rivers. Org. Geochem. 40, 1151-1159.

Coolen M. J. L., Talbot H. M., Abbas B. A., Ward C., Schouten S., Volkman J. K. and Sinninghe Damsté J. S. (2008) Sources for sedimentary bacteriohopanepolyols as revealed by $16 \mathrm{~S}$ rDNA stratigraphy. Environ. Microbiol. 10, 1783-1803.

Crossman Z. M., Mc Namara N., Parekh N., Ineson P. and Evershed R. P. (2001) A new method for identifying the origins of simple and complex hopanoids in sedimentary materials using stable isotope labelling with ${ }^{13} \mathrm{CH}_{4}$ and compound specific stable isotope analyses. Org. Geochem. 32, 359-364.

Cvejic J. H., Bodrossy L., Kovács K. L. and Rohmer M. (2000) Bacterial triterpenoids of the hopane series from the methanotrophic bacteria Methylocaldum spp.: phylogenetic implications and first evidence for an unsaturated aminobacteriohopanepolyol. FEMS Microbiol. Lett. 182, 361365.

De Conto R., Galeotti S., Pagani M., Tracy D., Schaefer K., Zhang T., Pollard D. and Beerling D. J. (2012) Past extreme warming events linked to massive carbon release from thawing permafrost. Nature 484, 87-92.

Dickens G. R., O’Neil J. R., Rea D. K. and Owen R. M. (1995) Dissociation of oceanic methane hydrate as a cause of the carbon isotope excursion at the end of the Paleocene. Paleoceanography 10, 965-971.

Dickens G. R. (2003) Rethinking the global carbon cycle with a large, dynamic and microbially mediated gas hydrate capacitor. Earth Planet. Sci. Lett. 213, 169-183.

Doğrul Selver A., Talbot H. M., Gustafsson Ö., Boult S. and van Dongen B. E. (2012) Soil organic matter transport along an sub-Arctic river-sea transect. Org. Geochem. 51, 63-72.

Eigenbrode J. L., Freeman K. H. and Summons R. E. (2008) Methylhopane biomarker hydrocarbons in Hamersley Province sediments provide evidence for Neoarchean aerobiosis. Earth Planet. Sci. Lett. 273, 323-331.

Eisma D., Kalf J. and Van der Gaast S. J. (1978) Suspended matter in the Zaire estuary and adjacent Atlantic Ocean. Neth. J. Sea Res. 12, 382-413.

Etiope G., Milkov A. V. and Derbyshire E. (2008) Did geological emission of methane play a role in Quaternary climate change? Global Planet. Change 61, 79-88.
Farrimond P., Head I. M. and Innes H. E. (2000) Environmental influence on the bio-hopanoid composition of recent sediments. Geochim. Cosmochim. Acta 64, 2895-2992.

Farrimond P., Talbot H. M., Watson D. F., Schulz L. K. and Wilhelms A. (2004) Methylhopanoids: molecular indicators of ancient bacteria and a petroleum correlation tool. Geochim. Cosmochim. Acta 68, 3873-3882.

Feng D., Chen D., Peckmann J. and Bohrmann G. (2010) Authigenic carbonates from methane seeps of the northern Congo fan: microbial formation mechanism. Mar. Pet. Geol. 27, 748-756.

Fischer H., Behrens M., Bock M., Richter U., Schmitt J., Loulergue L., Chappellaz J., Spahni R., Blunier T., Leuenberger M. and Stocker T. F. (2008) Changing boreal methane sources and constant biomass burning during the last termination. Nature 452, 864-867.

Gay A., Lopez M., Cochonat P., Séranne M., Levaché D. and Sermondadaz G. (2006a) Isolated seafloor pockmarks linked to BSRs, fluid chimneys, polygonal faults and stacked OligoceneMiocene turbiditic palaeochannels in the Lower Congo Basin. Mar. Geol. 226, 25-40.

Gay A., Lopez M., Ondreas H., Charlou J. L., Sermondadaz G. and Cochonat P. (2006b) Seafloor facies related to upward methane flux within a Giant Pockmark of the Lower Congo Basin. Mar. Geol. 226, 81-95.

Gay A., Lopez M., Berndt C. and Séranne M. (2007) Geological controls on focused fluid flow associated with seafloor seeps in the Lower Congo Basin. Mar. Geol. 244, 68-92.

Gibson R. A., Kaur P., Pancost R. D., Mountain B. and Talbot H. M. (2008) Bacteriohopanepolyol signatures of cyanobacterial and methanotrophic bacterial populations recorded in a geothermal vent sinter. Org. Geochem. 39, 1020-1023.

Handley L., Talbot H. M., Cooke M. P., Anderson K. E. and Wagner T. (2010) Diverse fully functionalised bacteriohopanepolyol distributions up to $1.2 \mathrm{Ma}$ in sediments from the Congo deep-sea fan. Org. Geochem. 41, 910-914.

Hanson R. S. and Hanson T. E. (1996) Methanotrophic bacteria. Microbiol. Rev., 439-471.

Hinrichs K. -U. (2001) A molecular recorder of methane hydrate destabilization. Geochem. Geophys. Geosys. 2, 2000GC000118.

Hinrichs K.-U., Hmelo L. R. and Sylva S. P. (2003) Molecular fossil record of elevated methane levels in late Pleistocene coastal waters. Science 299, 1214-1217.

Holmes M. E., Schneider R. R., Müller P. J., Segl M. and Wefer G. (1997) Reconstruction of past nutrient utilization in the Eastern Angola Basin based on sedimentary ${ }^{15} \mathrm{~N} /{ }^{14} \mathrm{~N}$ ratios. Paleoceanography 12, 604-614.

Holtvoeth J., Wagner T., Horsfield B., Schubert C. J. and Wand U. (2001) Late-Quaternary supply of terrigenous organic matter to the Congo deep-sea fan (ODP site 1075): implications for equatorial African palaeoclimate. Geo-Mar. Lett. 21, 23-33.

Innes H. E., Bishop A. N., Head I. M. and Farrimond P. (1997) Preservation and diagenesis of hopanoids in recent lacustrine sediments of Priest Pot. Org. Geochem. 26, 565-576.

IPCC 2007. Summary for policymakers. In Climate change 2007: the physical science basis. Contribution of working group I to the fourth assessment report of the intergovernmental panel on climate change (eds. S. Solomo et al.). Cambridge University Press, Cambridge.

Jahn B., Schneider R. R., Müller P. -J., Donner B. and Röhl U. (2005) Response of tropical African and East Atlantic climates to orbital forcing over the last 1.7 Ma. Geol. Soc., Lond. Special Publ. 247, 65-84.

Jahnke L. L., Summons R. E., Dowling L. M. and Zahiralis A. D. (1995) Identification of methanotrophic lipid biomarkers in 
cold-seep mussel gills: chemical and isotopic analysis. Appl. Environ. Microbiol. 61, 576-582.

Jahnke L. L., Summons R. E., Hope J. M. and Des Marais D. J. (1999) Carbon isotopic fractionation in lipids from methanotrophic bacteria II: the effects of physiology and environmental parameters on the biosynthesis and isotopic signatures of biomarkers. Geochim. Cosmochim. Acta 63, 79-93.

Jorgensen B. B. and Kasten S. (2006) Sulfur cycling and methane oxidation. In Marine Geochemistry (eds. H. D. Schulz and M. Zabel), second ed. Springer-Verlag, Germany.

Kasting J. F. (2005) Methane and climate during the Precambrian era. Precambr. Res. 137, 119-129.

Kemp D. B., Coe A. L., Cohen A. S. and Schwark L. (2005) Astronomical pacing of methane release in the Early Jurassic period. Nature 437, 396-399.

Kennett J. P., Cannariato K. G., Hendy I. L. and Behl R. J. (2003) Methane hydrates in Quaternary climate change: the clathrate gun hypothesis, Special Publication. AGU, p. 216.

Kim J.-H., Talbot H. M., Zarzycka B., Bauersach T. and Wagner T. (2011) Occurrence and abundance of soil-specific bacterial membrane lipid markers in the Têt watershed (Southern France): soil-specific BHPs and branched GDGTs. Geochem. Geophys. Geosyst. http://dx.doi.org/10.1029/2010GC003364.

Kroeger K. F., di Primo R. and Horsfield B. (2011) Atmospheric methane from organic carbon mobilization in sedimentary basins - the sleeping giant? Earth-Sci. Rev. 107, 423-442.

Lisiecki L. E. and Raymo M. E. (2005) A Pliocene-Pleistocene stack of 57 globally distributed benthic ${ }^{18} \mathrm{O}$ records. Paleoceanography 20, PA1003.

Loulergue L., Schilt A., Spahni R., Masson-Delmotte V., Blunier T., Lemieux B., Barnola J.-M., Raynaud D., Stocker T. F. and Chappellaz J. (2008) Orbital and millennial-scale features of atmospheric $\mathrm{CH}_{4}$ over the past 800,000 years. Nature $453,383-$ 386.

Melack J. M. and Hess L. L. (2010) Remote sensing of the distribution and extent of Wetlands in the Amazon Basin. In Amazonian Floodplain Forets - Ecophysiology, Biodiversity, and Sustainable Management (eds. W. J. Junk, F. Wittmann, P. Parolin, M. T. F. Piedade and J. Schöngart). Springer, Dordrecht, pp. 43-60.

Menot G. and Bard E. (2010) Geochemical evidence for a large methane release during the last deglaciation from Marmara Sea sediments. Geochim. Cosmochim. Acta 74, 1537-1550.

Neunlist S. and Rohmer M. (1985a) Novel hopanoids from the methylotrophic bacteria Methylococcus capsulatus and Methylomonas methanica. (22S)-35-aminobacteriohopane30,31,31,33,34-pentol and (22S)-35-amino-3 $\beta$-methyl-bacteriohopane-30,31,32,33,34-pentol. Biochem. J. 231, 635-639.

Neunlist S. and Rohmer M. (1985b) The hopanoids of Methylosinus trichosporium: aminobacteriohopanetriol and aminobacteriohopanetetrol. J. Gen. Microbiol. 131, 1363-1367.

Noethen K. and Kasten S. (2011) Reconstructing changes in seep activity by means of pore water and solid phase $\mathrm{Sr} / \mathrm{Ca}$ and $\mathrm{Mg}$ / $\mathrm{Ca}$ ratios in pockmark sediments of the Northern Congo Fan. Mar. Geol. 287, 1-13.

Norris R. D. and Roehl U. (1999) Carbon cycling and chronology of climate warming during the Palaeocene/Eocene transition. Nature 401, 775-755.

Pancost R. D., Zhang C. L., Tavacoli J., Talbot H. M., Farrimond P., Schouten S. and Sinninghe Damsté J. S. (2005) Archaeal lipid biomarkers and isotopic evidence of anaerobic methane oxidation associated with gas hydrates in the Gulf of Mexico. Palaeogeogr. Palaeoclimatol. Palaeoecol. 227, 48-66.

Peckmann J. and Thiel V. (2004) Carbon cycling at ancient methane-seeps. Chem. Geol. 205, 443-467.
Reeburgh W. S. (2007) Oceanic methane biogeochemistry. Chem. Rev. 107, 486-513.

Rohmer M., Bouvier-Navé P. and Ourisson G. (1984) Distribution of hopanoid triterpenes in prokaryotes. J. Gen. Microbiol. 130, $1137-1150$.

Sáenz J. P., Eglinton T. I. and Summons R. E. (2011a) Abundance and structural diversity of bacteriohopanepolyols in suspended particulate matter along a river to ocean transect. Org. Geochem. 42, 774-780.

Sáenz J. P., Wakeham S. G., Eglinton T. I. and Summons R. E. (2011b) New constraints onthe provenance of hopanoids in the marine geologic record: bacteriohopanepolyols in marine suboxic and anoxic environments. Org. Geochem. 42, 1351-1362.

Sahling H., Bohrmann G., Spiess V., Bialas J., Breitzke M., Ivanov M., Kasten S., Krastel S. and Schneider R. R. (2008) Pockmarks in the Northern Congo Fan area, SW Africa: Complex seafloor features shaped by fluid flow. Mar. Geol. 249, 206-225.

Schneider R. R., Müller P. J., Kroon D., Price B. and Alexander I. (1997) Monsoon related variations in Zaire (Congo) sediment load and influence of fluvial silicate supply on marine productivity in the east equatorial Atlantic during the last 200,000 years. Paleoceanography 12, 463-481.

Schneider R. R., Müller P. J. and Wefer G. (1994) Late Quaternary paleoproductivity changes off the Congo deduced from stable carbon isotopes of planktonic foraminifera. Palaeogeogr. Palaeoclimatol. Palaeoecol. 110, 255-274.

Shackleton N. J., Berger A. and Peltier W. R. (1990) An alternative astronomical calibration of the lower Pleistocene timescale based on ODP Site 677. Trans. R. Soc. Edinburgh: Earth Sci. 81, 251-261.

Schefuß E., Schouten S., Jansen J. H. F. and Sinninghe Damsté J. S. (2003) African vegetation controlled by tropical sea surface temperatures in the mid-Pleistocene period. Nature 422, 418421.

Schefuß E., Versteegh G. J. M., Jansen J. H. F. and Sinninghe Damsté J. S. (2004) Lipid biomarkers as major source and preservation indicators in SE Atlantic surface sediments.. DeepSea Res., Part I 51, 1199-1228.

Schefuß E., Schouten S. and Schneider R. R. (2005) Climatic controls on central African hydrology during the past 20,000 years. Nature 437, 1003-1006.

Singarayer J. S., Valdes P. J., Friedlingstein P., Nelson S. and Beerling D. J. (2011) Late Holocene methane rise caused by orbitally controlled increase in tropical sources. Nature 470, 8285.

Spencer R. G. M., Hernes P. J., Aufdenkampe A. K., Baker A., Gulliver P., Stubbins A., Aiken G. R., Dyda R. Y., Butler K. D., Mwamba V. L., Mangangu A. M., Wabakanghanzi J. N. and Six J. (2012) An initial investigation into the organic matter biogeochemistry of the Congo River. Geochim. Cosmochim. Acta 84, 614-627.

Spencer R. G. M., Stubbins A. and Gaillardet J. (2013) Geochemistry of the Congo River, estuary and plume. In Biogeochemical Dynamics at Large River-Coastal Interfaces: Linkages with Global Climate Change (eds. T. S. Bianchi, M. A. Allison and W. J. Cai). Cambridge University Press.

Sultan N., Foucher J. P., Cochonat P., Tonnerre T., Bourillet J. F., Ondreas H., Cauquil E. and Grauls D. (2004) Dynamics of gas hydrate: case of the Congo continental slope. Mar. Geol. 206, $1-18$.

Summons R. E., Jahnke L. L. and Roksandic Z. (1994) Carbon isotopic fractionation in lipids from methanotrophic bacteria: relevance for interpretation of the geochemical record of biomarkers. Geochim. Cosmochim. Acta 58, 2853-2863. 
Talbot H. M. and Farrimond P. (2007) Bacterial populations recorded in diverse sedimentary biohopanoid distributions. Org. Geochem. 38, 1212-1225.

Talbot H. M., Watson D. F., Murrell J. C., Carter J. F. and Farrimond P. (2001) Analysis of intact bacteriohopanepolyols from methanotrophic bacteria by reversed phase high performance liquid chromatography - atmospheric pressure chemical ionisation - mass spectrometry. J. Chromatogr. A 921, 175-185.

Talbot H. M., Watson D. F., Pearson E. J. and Farrimond P. (2003) Diverse hopanoid compositions in non-marine sediments. Org. Geochem. 34, 1353-1371.

Talbot H. M., Summons R. E., Jahnke L. L., Cockell C. S., Rohmer M. and Farrimond P. (2008) Cyanobacterial bacteriohopanepolyol signatures from cultures and natural environmental settings. Org. Geochem. 39, 232-263.

Thiel V., Blumenberg M., Pape T., Seifert R. and Michaelis W. (2003) Unexpected occurrence of hopanoids at gas seeps in the Black Sea. Org. Geochem. 34, 81-87.

Tyler S. C., Rice A. L. and Ajie H. O. (2007) Stable isotope ratios in atmospheric $\mathrm{CH} 4$ : implications for seasonal sources and sinks. J. Geophys. Res. 112, D03303. http://dx.doi.org/10.1029/ 2006JD0072311.

Uchida M., Shibata Y., Ohkushi K., Ahagon N. and Hoshiba M. (2004) Episodic methane release events from Last Glacial marginal sediments in the western North Pacific. Geochem. Geophys. Geosyst. 5, N8.

van Winden J. F., Kip N., Reichart G.-J., Pol A., Jetten M. S. M., Op den Camp H. J. M. and Sinninghe Damsté J. S. (2010) Lipids of symbiotic methane-oxidizing bacteria in peat moss studied using stable carbon isotopic labeling. Org. Geochem. 41, 1040-1044.

van Winden J. F., Talbot H. M., Kip N., Reichart G.-J., Pol A., McNamara N. P., Jetten M. S. M., Op den Camp H. J. M. and Sinninghe Damsté J. S. (2012a) Bacteriohopanepolyol signatures as markers for methanotrophic bacteria in peat moss. Geochim. Cosmochim. Acta 77, 52-61.

van Winden J. F., Talbot H. M., De Vleeschouwer F., Reichart G.J. and Sinninghe Damsté J. S. (2012b) Variation in methanotroph-related proxies in peat deposits from Misten Bog, Hautes-Fagnes, Belgium. Org. Geochem. 53, 73-79.

Valentine D. L. (2011) Emerging topics in marine methane biogeochemistry. Annu. Rev. Mar. Sci. 3, 147-171.

Valentine D. L., Blanton D. C., Reeburgh W. S. and Kastner M. (2001) Water column methane oxidation adjacent to an area of active hydrate dissociation, Eel River Basin. Geochim. Cosmochim. Acta 65, 2633-2640.

Wagner T., Stüsser I., Schouten S., Herrle J. O., Hofmann P. and Sinninghe Damsté J. S. (2008) Rapid warming and salinity changes of Cretaceous surface waters in the subtropical North Atlantic. Geology 36, 203-206.

Wagner T., Wallmann K., Stüsser I., Herrle J. O. and Hofmann P. (2007) Consequences of moderate $\sim 25,000$ yr lasting emission of light $\mathrm{CO}_{2}$ into the mid-Cretaceous ocean. Earth Planet. Sci. Lett. 259, 200-211.
Wagner T., Kallweit W., Talbot H. M., Mollenhauer G., Boom A. and Zabel M. (2014) Microbial biomarkers support organic carbon transport from Amazon wetlands to the shelf and deep fan during recent and glacial climate conditions. Org. Geochem. 67, 85-98.

Wakeham S. G., Amann R., Freeman K. H., Hopmans E., Jørgensen B. B., Putnam I. F., Schouten S., Sinninghe Damsté J. S., Talbot H. M. and Woebken D. (2007) Microbial ecology of the stratified water column of the Black Sea as revealed by a comprehensive biomarker study. Org. Geochem. 38, 20702097.

Watson D. F. (2002) Environmental distribution and sedimentary fate of hopanoid biological marker compounds. Ph. D. Thesis, University of Newcastle, UK.

Wefer G., Berger W. H. and Richter C., et al. (1998) Proceedings of the ODP, Initial Reports College Station, Texas (Ocean Drilling Program), Vol. 175, 49-86. doi:10.2973/ odp.proc.ir.175.103.1998.

Welander P. V. and Summons R. E. (2012) Discovery, taxonomic distribution, and phenotypic characterization of a gene required for 3-methylhopanoid production. Proc. Natl. Acad. Sci. USA 109, 12905-12910.

West S., Jansen J. H. F. and Stuut J.-B. (2004) Surface water conditions in the Northern Benguela Region (SE Atlantic) during the last $450 \mathrm{ky}$ reconstructed from assemblages of planktonic foraminifera. Mar. Micropaleontol. 51, 321-344.

Wuebbles D. J. and Hayhoe K. (2002) Atmospheric methane and global change. Earth Sci. Rev. 57, 177-210.

Zhang C. L., Huang Z., Li Y.-L., Romanek C. S., Mills G., Gibson R. A., Talbot H. M., Wiegel J., Noakes J., Culp R. and White D. C. (2007) Lipid biomarkers, carbon isotopes and phylogenetic characterisation of bacteria in California and Nevada hot springs. Geomicrobiol J. 24, 519-534.

Zeebe R. E., Zachos J. C. and Dickens G. R. (2009) Carbon dioxide forcing alone insufficient to explain Palaeocene-Eocene Thermal Maximum warming. Nat. Geosci. 2, 576-580.

Zhou P., Berova N., Nakanishi K., Knani M. and Rohmer M. (1991) Microscale CD method for determining absolute configurations of acyclic amino tetrols and amino pentols. Structures of aminobacteriohopanepolyols from the methylotrophic bacterium Methylococcus luteus. J. Am. Chem. Soc. 113, 40404042.

Zhu C., Talbot H. M., Wagner T., Pan J.-M. and Pancost R. D. (2010) Intense aerobic methane oxidation in the yangtze estuary: a record from 35-aminobacteriohopanepolyols in surface sediments. Org. Geochem. 41, 1056-1059.

Zhu C., Talbot H. M., Wagner T., Pan J.-M. and Pancost R. D. (2011) Distribution of hopanoids along a land to sea transect: implications for microbial ecology and the use of hopanoids in environmental studies. Limnol. Oceanogr. 56, $1850-1865$. 